Article

\title{
Experimental Study of the Effect of Fuel Catalytic Additive on Specific Fuel Consumption and Exhaust Emissions in Diesel Engine
}

\author{
Marcin Tkaczyk (D), Zbigniew J. Sroka*D, Konrad Krakowian (D) and Radoslaw Wlostowski \\ Department of Automotive Engineering, Wroclaw University of Science and Technology, \\ PL 50-370 Wroclaw, Poland; marcin.tkaczyk@pwr.edu.pl (M.T.); konrad.krakowian@pwr.edu.pl (K.K.); \\ radoslaw.wlostowski@pwr.edu.pl (R.W.) \\ * Correspondence: zbigniew.sroka@pwr.edu.pl; Tel.: +48-71-340-19-18
}

check for updates

Citation: Tkaczyk, M.; Sroka, Z.J.;

Krakowian, K.; Wlostowski, R.

Experimental Study of the Effect of Fuel Catalytic Additive on Specific Fuel Consumption and Exhaust Emissions in Diesel Engine. Energies 2021, 14, 54. https://dx.doi.org/ 10.3390/en14010054

Received: 10 November 2020 Accepted: 19 December 2020 Published: 24 December 2020

Publisher's Note: MDPI stays neutral with regard to jurisdictional claims in published maps and institutional affiliations.

Copyright: $@ 2020$ by the authors. Licensee MDPI, Basel, Switzerland. This article is an open access article distributed under the terms and conditions of the Creative Commons Attribution (CC BY) license (https: / creativecommons.org/ licenses/by/4.0/).

\begin{abstract}
Fuel catalytic additives have been tested for many years. Herein, their influence on the overall efficiency of combustion engines is investigated, and their pro-ecological impact is assessed. The majority of this research concerns diesel engines. Despite many advantages, to this day, the use of catalytic additives has not become widespread. Wishing to clarify the situation, a research group from the Wroclaw University of Science and Technology decided to investigate this matter, starting with verification tests. This article presents the methodology and results of testing an actual diesel engine, and evaluates the effects of the use of a fuel catalytic additive. The focus was on the analysis of fuel consumption and exhaust gas emissions from a Doosan MD196TI engine. The tested additive was a commercial fuel performance catalyst (FAMAX) with up to $5 \%$ ferric chloride as an organometallic compound. The proportion of the mixture with the fuel was 1:2000. These studies provide an energy and ecological assessment of propulsion in inland vehicles relative to current exhaust emission standards. The tests were carried out in accordance with the ISO 8178 standard, albeit on a much broader scale regarding engine operation than required by the standard. In this way, a set of previously published data was more than doubled in scope. Detailed conclusions indicate the positive effect of the tested fuel additive. The emission values decreased, on average by $16.7 \%$ for particulate matter (PM), 10.1\% for carbon monoxide (CO), and 7.9\% for total hydrocarbons (THC). Unfortunately, the amount of nitrogen oxides (NOx) increased by $1.2 \%$. The average difference in specific fuel consumption (BSFC) between the fuel with additive and pure diesel fuel was $0.5 \%$, i.e., below the level of measurement error. The authors formulated the following scientific relationship between the thermal efficiency of the engine and the operation of the catalyst: the effect of the catalyst on the combustion process decreases with the increase of the thermodynamic efficiency of the engine. This conclusion indicates that despite the proven positive effect of catalysts on the combustion process, they can only be used in markets where engines with low thermal efficiency are used, i.e., older generation engines.
\end{abstract}

Keywords: diesel engines; fuel additives; specific fuel consumption; emissions

\section{Introduction}

Diesel engines are widely used, especially in heavy road transport and various nonroad applications such as construction machinery, agricultural tractors as well as in sea and inland navigation.

The main factor determining the suitability of an internal combustion engine to a selected application is compliance with the appropriate regulations. In the European Union, the use of engines for off-road applications, including inland navigation, is subject to the Regulations of the European Parliament of 14 September 2016, which came into force on 1 January 2019. The exhaust gas emission levels, referred to as Stage IIIa, have been changed to new Stage V values. The changing legal situation has resulted in a lack of 
demand for engines in the power range from 130 to $300 \mathrm{~kW}$. In Poland, none of the companies distributing internal combustion engines for inland navigation was able to deliver a brand new engine meeting the above requirements.

This situation has brought about the need to work on the adaptation of existing engines to make them compliant with current requirements. Actions involving structural changes are usually difficult and time-consuming; therefore, it was decided to use a modified fuel in the first step of meeting the standards, which, according to current knowledge, changes the combustion process by accelerating thermo-chemical reactions.

One of the known methods of accelerating the combustion process in diesel engines is the addition of homogeneous combustion catalysts to diesel fuel [1]. Homogeneous combustion catalysts have several features that favor their use: they dissolve homogeneously in diesel fuel, show high catalytic activity in supporting the combustion of hydrocarbons, even at low levels, i.e., of the order of ppm, secondary emission problems are negligible or nonexistent, and additives do not precipitate out during storage or engine operation [2]. In many studies, favorable results were observed using metal ions such as iron [3-8], barium [9,10], cerium [11-15], manganese [16], copper [17], platinum [18-20], and sodium [21].

One solution is a catalytic fuel additive containing organometallic metal or nanoparticles. It was developed and researched by Zhang, Ma, and Zhu [1,22]. The creators of the technology argued that such a solution ensures the best mixing with diesel fuel. A conclusion was also published about the advantages of iron in catalysts over other metals due to its low environmental impact. During combustion with such a catalyst, iron oxides are produced, which are less toxic than other metal oxides [23-25]. The publication [26] illustrates the effectiveness of promoting the combustion process thanks to the use of iron picrate, which is an organometallic compound made under controlled conditions from compounds containing iron and picric acid. This fuel performance catalyst (FPC) was commercially introduced by Fuel Technology Pty Ltd.; Perth, Western Australia [27].

Commercialization increased the availability of the product, further research is being conducted on the impact of FPCs on engine operation indicators. Many laboratory experiments and in situ tests have been carried out, especially by the Center for Energy at the University of Western Australia. Research at this institution focused on two issues: the first was to assess the effect of using ferric picrate as an additive to diesel fuel, and the second was to evaluate its impact on the combustion process and on biodiesel emissions $[1,4,6,22,28]$. The research resulted in the systematization of knowledge about fuel additives, and confirmed previously published results regarding their effectiveness. The conclusions emphasized that the effect of FPCs depends on the size of the engine and the form of operation. Savings in fuel consumption ranged from $1.1-7.0 \%[22,28,29]$. In the same publications, one can also find correlations among fuel efficiency and engine speed and load. This fact was recognized by the authors as follows: levels of emission reduction with the use of FPC catalysts are more significant in inefficient engine operation modes. In [30], fuel consumption during the operation of Caterpillar 793C trucks transporting soil in a mine in Western Australia was measured. It was shown that fuel consumption decreased by $2.5 \%$ with a confidence level of $97 \%$. In addition, in the same field trial, a reduction in the emission of PM particulates by $39.5 \%$, carbon monoxide by $22.5 \%$, and UHC hydrocarbons by $15.3 \%$ was observed, as well as an increase in $\mathrm{NO}_{x}$ emissions by $8.3 \%$.

On the basis of experimental and theoretical analyses, in [4], the authors described attempts to explain the mechanism of operation of a fuel catalyst containing iron. It appears that under the influence of heat (a temperature of just $523 \mathrm{~K}$ is sufficient) in a diesel engine, iron picrate decomposes and releases iron atoms into the reaction zone. This promotes the oxidation of fuel molecules and increases the reaction rate, as well as increasing the flame zone. As a consequence, there is increased heat transfer to the unburned fuel, resulting in a shorter combustion time and a more complete process. Iron atoms, as nonflammable particles, are ejected along with the exhaust gases and do not pollute the ambient air. These conclusions are consistent with the literature based on the observation 
that a small amount of iron in the flame may support ignition and increase the rates of combustion of hydrogen [31,32], carbon monoxide [33], and methane [34].

In other tests, the same research group [3] explained the effect of FPC catalysts on the soot formation mechanism. It was found that the sizes of the primary soot and aggregates from the catalyzed diesel fuel were consistently smaller than those of pure diesel fuel. This means that the FPC affects the combustion process, thus making the process close to the complete; as a result there is less soot in the exhaust gas. These results are consistent with studies by other authors [35-37] who demonstrated soot oxidation by the deposition of FPC inside the soot particles. It was shown that a small amount of transition metals or metal oxides can significantly increase the oxidation rate of soot. The authors of $[3,22]$ also showed the economic benefit of using FPCs.

Fuel-borne graphene quantum dots have also been shown to reduce fuel consumption by $14 \%$ when compared to pure diesel fuel [38].

In view of the broad but varied advantages of the use of FPCs, the authors of this study decided to undertake research on the transformation of an inland navigation engine in order to meet the current Stage V exhaust emission standards.

A study was conducted on one of the available FPC additives, distributed under the name Fuel Maximizer (FMAX) with the composition shown in Table 1.

Table 1. FMAX composition [39].

\begin{tabular}{cc}
\hline Ingredient & Proportion wt\% \\
\hline Naphtha Petroleum & $60-100 \%$ \\
\hline Naphthalene & $3-7 \%$ \\
\hline Organometallic Compounds & $1-5 \%$ \\
\hline 1,2,4-Trimethylbenzene & $0.1-1 \%$ \\
\hline
\end{tabular}

The percentage of ferric chloride in FMAX is in the range of $1-5 \%$.

An additional intention of the present research was to assess the uneven interest of various markets in the aforementioned additive despite its technical and economic advantages. This article presents the results of tests performed in a laboratory on an engine built in accordance with ISO 81789, although the scope of the tests is much more extensive than what is required by the standard.

The obtained results concern various indicators of engine operation, but most of all, they refer to fuel consumption and exhaust gas emissions, which are directly correlated with thermal efficiency that, in turn, defines the nature of the combustion process. Fuel consumption and emissions of particulates, nitrogen oxides, carbon monoxide, and hydrocarbons were analyzed according to load and engine speed. The differences in fueling with standard diesel oil and diesel fuel with FMAX additive are presented.

The scope of the tests went far beyond mere approval tests, as measurements were carried out on 32 engine operating characteristics, thereby providing a comprehensive image of the field of operation. The innovative part of the tests was the use of an engine with a thermal efficiency that was more than twice as high as that presented in other publications.

This article summarizes the advantages of FPCs in the form of reducing the average (i.e., over the entire engine operating range) emissions of particulate matter (PM) by $16.7 \%$, carbon monoxide (CO) by $10.1 \%$, and total hydro carbons (THC) $7.9 \%$, and specific fuel consumption (BSFC) by $0.5 \%$, as well as the disadvantage in the form of an increase in nitrogen oxide $\left(\mathrm{NO}_{\mathrm{x}}\right)$ emissions by $1.2 \%$. The most important conclusion in comparison with the research of others is as follows: if the efficiency of the engine is higher, the impact of the fuel catalyst on the efficiency of the combustion process is smaller. 


\section{Research Methodology}

\subsection{Measurement Procedure}

The test methodology adopted for the verification of the FPC catalyst was based on engine tests in the full range of engine operation. Such a method enables a realistic assessment of the effects of the use of a catalyst without narrowing the operating field according to the engine application (in this case, a marine engine).

Extensive research is an important aspect of this project, because the obtained data, their analysis, and conclusions are responses to the effect of the use of a fuel catalyst for an entire family of engines, and not only for the type or model of engine used in a specific facility or industry. This test methodology covers the ISO8178 standard but its range is wider.

It should be emphasized that the test results contained in this publication can be grouped according to application. The only narrowing of the standardized scope of tests was the use of an eddy current dynamometer, which made it impossible to perform dynamic tests; nonetheless, the use of such a device is acceptable for tests of nonroad engines. The present research was related to the Commission Delegated Regulation (EU) 2017/655 of 19 December 2016 supplementing Regulation (EU) 2016/1628 of the European Parliament with regard to the monitoring of gaseous pollutant emissions from in-service internal combustion engines installed in nonroad mobile machinery. These regulations refer to tests performed in accordance with ISO 8178 carried out on a test stand with the use of a laboratory dynamometer.

It should be noted that the established research methodology was different from that which is in force today for other applications, e.g., light motor vehicles. The Real Driving Emissions (RDE) procedure is more widely used to verify of the EURO VI standard. The authors of this publication are aware of these solutions, emphasizing, however, that their research was carried out in order to modernize nonroad engines to meet the Stage $\mathrm{V}$ standard. Extensive documentation and an analysis of RDE tests are presented in [40].

The bench was equipped with a brand new Doosan MD196TI internal combustion engine powered by either:

1. Standard fuel-pure diesel, or

2. Diesel fuel with catalytic additives (in a proportion of 2000: 1).

The experiment plan sought to undertake measurements of 39 aspects engine performance, as indicated in Table 2.

Table 2. Matrix of test measurement points.

\begin{tabular}{cccccccc}
\hline \multirow{2}{*}{ Engine Speed, rpm } & \multicolumn{7}{c}{ Brake Mean Effective Pressure, MPa } \\
\cline { 2 - 9 } & $\mathbf{0 . 0 5}$ & $\mathbf{0 . 1 6}$ & $\mathbf{0 . 2 7}$ & $\mathbf{0 . 3 8}$ & $\mathbf{0 . 4 9}$ & $\mathbf{0 . 6 0}$ & $\mathbf{0 . 7 1}$ \\
\hline 1000 & 1 & 2 & 3 & 4 & 5 & 6 & - \\
\hline 1200 & 7 & 8 & 9 & 10 & 11 & 12 & 13 \\
\hline 1400 & 14 & 15 & 16 & 17 & 18 & 19 & 20 \\
\hline 1600 & 21 & 22 & 23 & 24 & 25 & 26 & 27 \\
\hline 1800 & 28 & 29 & 30 & 31 & 32 & 33 & - \\
\hline 2000 & 34 & 35 & 36 & 37 & 38 & 39 & - \\
\hline
\end{tabular}

The order in which the measurements were carried out was in accordance with the numbering in Table 1 . The variables with the highest load $(0.71 \mathrm{MPa})$ and extreme engine speeds $(1000,1800$ and $2000 \mathrm{rpm})$ were not measurable using the applied engine.

In addition, despite multiple repetitions and support from the manufacturer of the measuring devices, data for emission tests in points 1, 2, 7, 14, 21, 28, 34 were not successfully obtained. Therefore, the aforementioned points were not taken into account 
when drawing up the conclusions. Thus, all calculations and analyses were based upon 32 measuring points.

Measurements of the engine operation indicators at each point consisted of achieving and stabilizing the set load and rotational speed values, and then recording the measured values for $4 \mathrm{~min}$.

The data were recorded on a computer dedicated to the laboratory stand. They were:

1. Engine speed.

2. Engine torque, transferred to engine power.

3. Fuel consumption by hour, converted into specific fuel consumption.

4. Concentrations of exhaust components, verified in emission values.

All calculations and analyses were made in accordance with ISO 8178. Thus, for each measuring point, according to the duration of the measurement, the values of rotational speed and torque were calculated, and then the average power value was determined. Having measurements of fuel consumption over time and relating them to average power values, specific fuel consumption (BSFC) was determined.

Assessments of the mass emissions of individual components of exhaust gases at each measurement point were performed taking into account the measured concentration values. As a result, the values of specific emissions were obtained.

\subsection{Fuel}

Pure diesel and the same fuel with the FPC were evaluated in terms of their physical and chemical properties; see Table 3.

Table 3. The physical and chemical parameters of tested fuel samples.

\begin{tabular}{|c|c|c|c|c|c|}
\hline Parameter & Test Methods & Unit & $\begin{array}{c}\text { Quality } \\
\text { Requirements of } \\
\text { Decree }\end{array}$ & Pure Diesel & $\begin{array}{c}\text { Fuel with Catalyst } \\
22.3 \mathrm{mg} / \mathrm{L}\end{array}$ \\
\hline Density at $15^{\circ} \mathrm{C}$ & $\begin{array}{c}\text { PN-EN ISO 12185: } \\
2002\end{array}$ & $\mathrm{~kg} / \mathrm{m}^{3}$ & $800.0 \div 840.0$ & 810.5 & 810.5 \\
\hline Sulfur content & $\begin{array}{c}\text { PN-EN ISO 20846: } \\
2012\end{array}$ & $\mathrm{mg} / \mathrm{kg}$ & $\max .10 .0$ & 4.8 & 4.8 \\
\hline Water content & $\begin{array}{c}\text { PN-EN ISO 12937: } \\
2005\end{array}$ & $\mathrm{mg} / \mathrm{kg}$ & $\max .200$ & 50 & 30 \\
\hline Cold filter plugging point & $\begin{array}{l}\text { PN-EN 116: } \\
\text { 2015-09 }\end{array}$ & ${ }^{\circ} \mathrm{C}$ & $\max .-32$ & -37 & -38 \\
\hline Cloud point & $\begin{array}{c}\text { PN-EN ISO 3015: } \\
1997\end{array}$ & ${ }^{\circ} \mathrm{C}$ & $\max .-22$ & -38 & -39 \\
\hline Flashpoint & $\begin{array}{c}\text { PN-EN ISO 2719: } \\
\text { 20016-08 }\end{array}$ & ${ }^{\circ} \mathrm{C}$ & over 55.0 & 60.5 & 60 \\
\hline Kinematic viscosity at $40^{\circ} \mathrm{C}$ & $\begin{array}{c}\text { PN-EN ISO 3104: } \\
2004\end{array}$ & $\mathrm{~mm}^{2} / \mathrm{s}$ & $1.500 \div 4.000$ & 1.708 & 1.647 \\
\hline $\begin{array}{c}\text { Polycyclic aromatic } \\
\text { Hydrocarbons }\end{array}$ & $\begin{array}{c}\text { PN-EN ISO 12916: } \\
2016-03\end{array}$ & $\%(m / m)$ & $\max .8 .0$ & 1.4 & 1.3 \\
\hline Cetane number & $\begin{array}{l}\text { PN-EN ISO 5165: } \\
2003\end{array}$ & - & $\min .51 .0$ & 53 & 53.1 \\
\hline Lubricity HFRR & $\begin{array}{c}\text { PN-EN ISO } \\
\text { 12156-1: 2016-04 }\end{array}$ & $\mu \mathrm{m}$ & $\max .460$ & 420 & 430 \\
\hline Oxidation stability & $\begin{array}{c}\text { PN-EN ISO 15751: } \\
2014-05\end{array}$ & $\mathrm{~h}$ & $\min .20 .0$ & $>30$ & $>30$ \\
\hline Oxidation stability & $\begin{array}{l}\text { PN-EN ISO 12205: } \\
\text { 2011 + Ap1: } 2013\end{array}$ & $\mathrm{~g} / \mathrm{m}^{3}$ & $\max .25$ & 4 & $<2$ \\
\hline
\end{tabular}


Table 3. Cont.

\begin{tabular}{|c|c|c|c|c|c|}
\hline Parameter & Test Methods & Unit & $\begin{array}{c}\text { Quality } \\
\text { Requirements of } \\
\text { Decree }\end{array}$ & Pure Diesel & $\begin{array}{l}\text { Fuel with Catalyst } \\
22.3 \mathrm{mg} / \mathrm{L}\end{array}$ \\
\hline $\begin{array}{l}\text { Copper strip corrosion } \\
\left(\mathrm{Cu} / 3 \mathrm{~h} / 50^{\circ} \mathrm{C}\right)\end{array}$ & $\begin{array}{l}\text { PN-EN ISO 2160: } \\
2004\end{array}$ & class 1 & class 1 & $1 \mathrm{a}$ & $1 \mathrm{a}$ \\
\hline FAME content & $\begin{array}{l}\text { PN-EN ISO 14078: } \\
2014-06\end{array}$ & $\%(v / v)$ & $\max .7 .0$ & $<0.5$ & $<0.5$ \\
\hline Total contamination & $\begin{array}{c}\text { PN -EN ISO 12662: } \\
\text { 2014-05 }\end{array}$ & $\mathrm{mg} / \mathrm{kg}$ & $\max .24 .0$ & $<12$ & $<12$ \\
\hline $\begin{array}{l}\text { Carbon residue on } 10 \% \\
\text { distillation residue }\end{array}$ & $\begin{array}{l}\text { PN-EN ISO 10370: } \\
2014-12\end{array}$ & $\%(m / m)$ & $\max .0 .30$ & $<0.10$ & $<0.10$ \\
\hline Ash content & $\begin{array}{l}\text { PN-EN ISO 6245: } \\
2008\end{array}$ & $\%(m / m)$ & $\max .0 .010$ & $<0.001$ & $<0.001$ \\
\hline Cetane index & $\begin{array}{l}\text { PN-EN ISO 4264: } \\
\text { 201O/A1: } 2013\end{array}$ & - & $\min .46 .0$ & 50.7 & 51 \\
\hline Manganese content & $\begin{array}{l}\text { PN-EN ISO 16576: } \\
2014-12\end{array}$ & $\mathrm{mg} / 1$ & $\max .2 .0$ & $<0.5$ & $<0.5$ \\
\hline Distillation-recovered at $180{ }^{\circ} \mathrm{C}$ & $\begin{array}{l}\text { PN-EN ISO 3405: } \\
2012\end{array}$ & $\%(v / v)$ & $\max .10 .0$ & 0.5 & 0.7 \\
\hline Distillation-recovered at $340^{\circ} \mathrm{C}$ & $\begin{array}{c}\text { PN-EN ISO 3405: } \\
2012\end{array}$ & $\%(v / v)$ & $\min .95$ & 98 & 98.5 \\
\hline
\end{tabular}

FPC was mixed with fuel in a proportion of 1:2000. This mixing ratio was chosen as a result of previous tests of vehicles in standard operation. Previous studies showed that a 1:2000 ratio yielded significant changes in PM emissions.

The results in Table 3 are consistent with those presented in the literature, and indicate a slight effect of the addition of FPC on fuel properties [2]. The fuel with the catalytic additive met the requirements of the EU fuel decree, although it is worth noting the factors that may have an impact on the combustion process, such as "distillation recovered at $180^{\circ} \mathrm{C}^{\prime \prime}$, which was $40 \%$ higher for FPC fuel than for pure fuel; this variable contributes to the acceleration of the combustion process and ensures more complete combustion, and thus, lower emission of toxic components in exhaust gases. The advantage of using FPC may also be due to the lower kinematic viscosity, i.e., an approx. 3.5\% reduction, and the lower water content for the FPC fuel, i.e., an approx. 30\% reduction.

The researchers also observed an increase in the lubricity and viscosity in the fuel with the additive. The complexity of the problem of research on the increase in viscosity in enriched fuels and, consequently, the increase in the life-span of the fuel equipment, is fully described in the literature [41]. Therefore, one could expect an increase in the life-span of the fuel equipment used in the analyzed case; however, this aspect was not the subject of this study.

\subsection{Test Stand}

The Doosan MD196TI diesel engine was tested; see Table 4 and Figure 1.

Table 4. Technical specifications of the Doosan MD196TI diesel engine [42].

\begin{tabular}{cc}
\hline Parameter & Specification \\
\hline Bore $\times$ Stroke & $123 \mathrm{~mm} \times 155 \mathrm{~mm}$ \\
\hline Cylinders arrangement & In line, 6 \\
\hline Displacement & $11.051 \mathrm{dm}^{3}$ \\
\hline
\end{tabular}


Table 4. Cont.

\begin{tabular}{cc}
\hline Parameter & Specification \\
\hline Fuel system & Diesel, Direct injection \\
\hline Governor type of injection pump & Mechanical variable speed (R.Q.V) \\
\hline Injection timing (B.T.D.C) & $16^{\circ} \pm 1^{\circ}$ \\
\hline Fuel injection nozzle opening pressure & 1 st: $16 \mathrm{MPa}, 2 \mathrm{nd}: 22 \mathrm{MPa}$ \\
\hline Mean effective pressure & $1.303 \mathrm{MPa}$ \\
\hline Rating output & $235 \mathrm{~kW} @ 2000 \mathrm{rpm}$ \\
\hline Specific fuel consumption @ rated power & $218 \mathrm{~g} / \mathrm{kWh}$ \\
\hline Emission standard & Stage IIIa \\
\hline
\end{tabular}

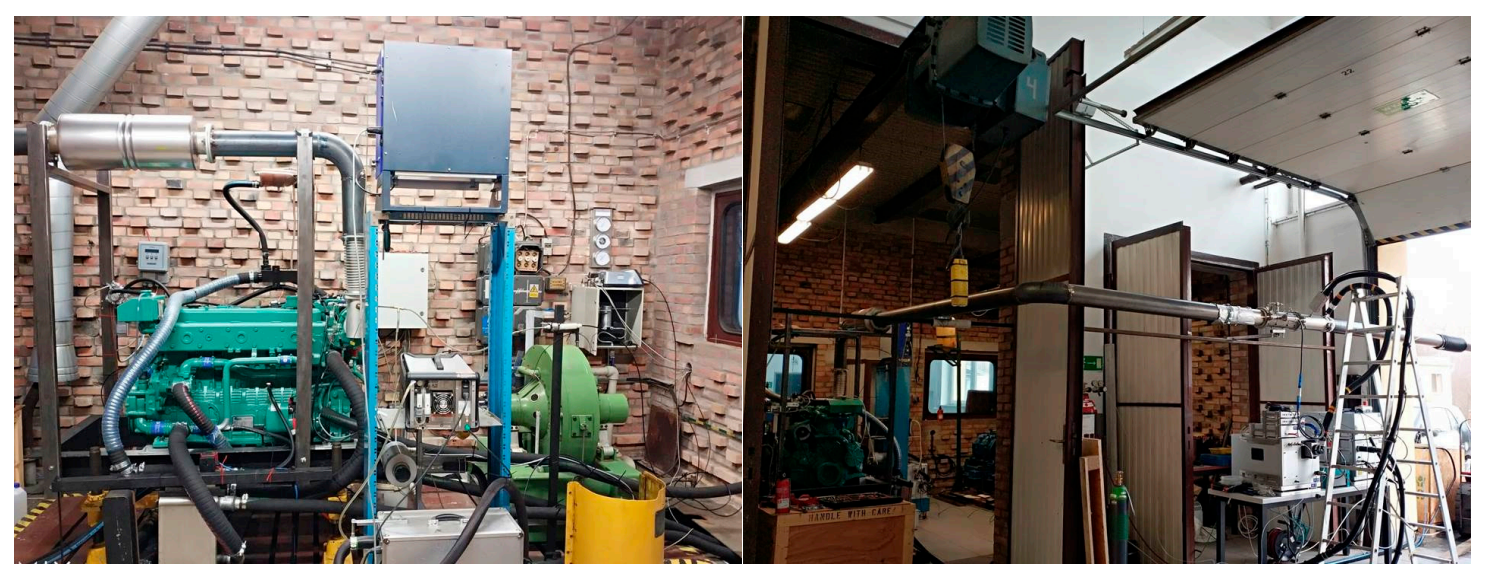

Figure 1. Diesel engine on the test stand in a laboratory at the Wroclaw University of Science and Technology.

The device loading the engine was an eddy current brake. The characteristics of the dynamometer made it possible to force a maximum torque of $2000 \mathrm{Nm}$ against the $1300 \mathrm{Nm}$ required for this engine. The dynamometer was able to operate at the highest engine speed, i.e., $5500 \mathrm{rpm}$ vs. the rated speed of the test engine, i.e., $2000 \mathrm{rpm}$. The measurement accuracy was $\pm 5 \%$ for torque and $\pm 2 \%$ for speed. Fuel consumption was measured using an AMX2400 fuel meter, manufactured by ODIUT Automex. Fuel flow measurements were conducted with both a gravimetric system and a Coriolis fuel flowmeter. Compatibility between both methods was within $1 \%$, even at very low flows. The measurement accuracy of the basic gravimetric method was $\pm 0.01 \mathrm{~g} / \mathrm{s}$. The stand was placed in the research laboratory of the Wroclaw University Science and Technology.

The concentrations of exhaust gas components were measured using a portable emission measurement system. Results were further subjected to postprocessing with the AVL Concerto 5 software, together with an AVL PM-PEMS iX. The accuracy of the emission test was $\pm 1 \%$, with repeatability in the range of $0.3 \%$ of the full scale. Raw exhaust gas with a flow of about $3.5 \mathrm{dm}^{3} / \mathrm{min}$ was sent to a heated filter via a heated pipe, where it was divided into two gas streams which were subsequently directed to appropriate meters. FID analyzers for the assessment of THC and CH4, UV-RAS for the measurement of NO and NOx, and NDIR for the assessment of $\mathrm{CO}$ and $\mathrm{CO}_{2}$ content, as well as an $\mathrm{O}_{2}$ probe, measured the concentrations of exhaust components with pressure compensation in ppm or \%vol. The obtained values were visualized via a user interface and processed using software provided by the device manufacturer; other tests using these tools are described detail in [40]. The accuracy of the emissions measurement equipment is shown in Table 5. 
Table 5. Technical specifications of the gas analyzer employed in this study.

\begin{tabular}{cccc}
\hline Parameters & Unit & Range & Accuracy \\
\hline $\mathrm{CO}$ & Vol, \% & $0-10$ & \pm 0.01 \\
\hline $\mathrm{PM}$ & $\mathrm{ppm}$ & $0-100 \%$ & \pm 1 \\
\hline $\mathrm{THC}$ & $\mathrm{ppm}$ & $0-10,000$ & \pm 1 \\
\hline $\mathrm{NO}_{\mathrm{x}}$ & $\mathrm{ppm}$ & $0-500$ & \pm 1 \\
\hline
\end{tabular}

The research scheme is shown in Figure 2.

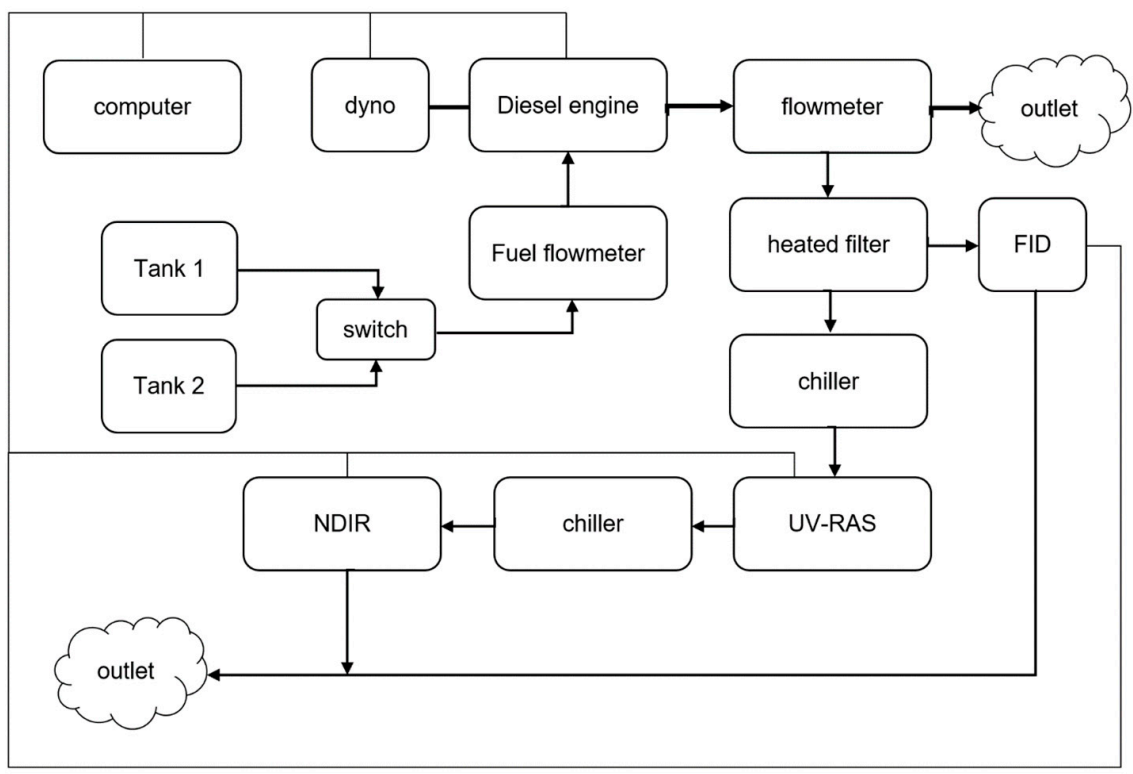

Figure 2. The measurement layout.

\section{Results with Discussion}

In accordance with the ISO 8178 standard and by way of completing the experiment plan, measurements were made at 32 points. The obtained results, given in mean values, are presented below, ensuring final conclusions related to the fulfillment of the scientific purpose of this research.

For the operating parameter of specific fuel consumption (BSFC), Table 6 shows the average values for the tested fuels, ranging from $185 \mathrm{~g} / \mathrm{kWh}$ to $266 \mathrm{~g} / \mathrm{kWh}$, regardless of the fuel used.

Table 6. Average specific fuel consumption for fuel tested.

\begin{tabular}{cc}
\hline & $\begin{array}{c}\text { Average } \\
\text { Specific Fuel Consumption } \\
\text { g/kWh }+/-\mathbf{1} \%\end{array}$ \\
\hline Pure diesel & 209 \\
\hline Diesel with FPC & 208 \\
\hline Relative difference, $\%$ & 0.5 \\
\hline
\end{tabular}

The difference shown in Table 4 is smaller than the measurement error, and therefore, cannot be considered significant. The difference in BSFC values between the combustion of pure diesel and fuel enriched with the catalyst is also smaller than the values obtained by Zhu, Ma and Zhang in $[22,28,29]$, which ranged from $1.1-7 \%$. To explain this, it should be emphasized that the presented tests covered a BMEP range from 0.16 to $0.71 \mathrm{MPa}$, 
while the tests presented in the works of $\mathrm{Zhu}, \mathrm{Ma}$ and Zhang covered a range from 0.13 to $0.41 \mathrm{MPa}$, i.e., an older generation engine was applied in their study. During their tests, fuel consumption was recorded in the range from 185 to $266 \mathrm{~g} / \mathrm{kWh}$, while in the case of research presented in [22,29], these values ranged from 325 to $625 \mathrm{~g} / \mathrm{kWh}$. This means that the average values of BSFC in the test conducted by the authors of this study were more than twice as low. Therefore, it can be concluded that, since the calorific values of the tested fuels were comparable, the efficiency of the tested engine was two times greater than that of the engine tested by researchers from the University of Western Australia [30].

To illustrate the details of the obtained results, an example data set in graphical form for various loads (BMEP) and at a constant rotational speed of $1200 \mathrm{rpm}$, which is recommended by the manufacturer for continuous operation, is presented in Figure 3.

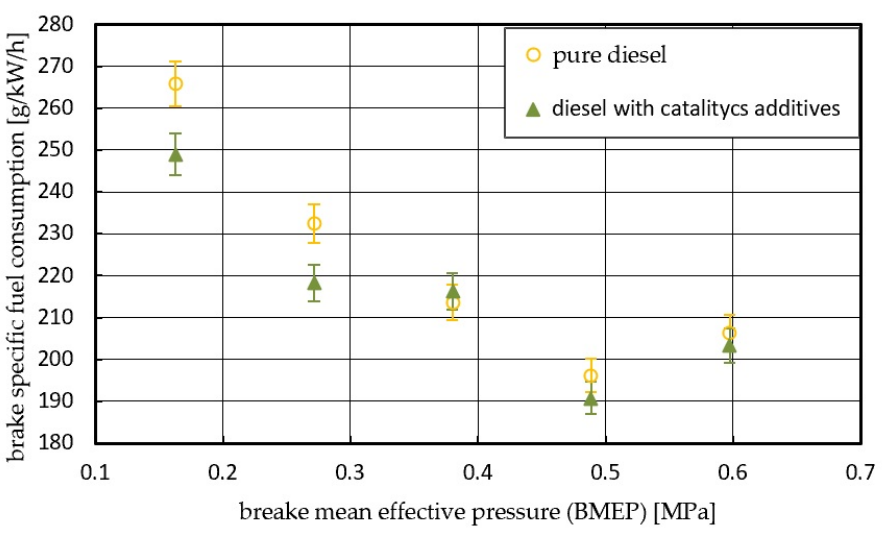

Figure 3. Brake-specific fuel consumption vs. brake mean effective pressure for pure diesel and fuel with catalytic additive at an engine speed of $2000 \mathrm{rpm}$.

The trend of changes in specific fuel consumption is typical for diesel engines. In evaluating two different fuel samples, i.e., with and without a fuel catalyst, the results showed a reduction in BSFC in the case of the former. The amounts of these differences depend on engine load. For lower load values, the difference was $6 \%$, and for higher loads, it was within the 3-5\% range. The overall reduction in fuel consumption with FPC, as well as the load-dependent trends (BMEP), can be explained using data from other publications. The observed phenomenon is similar to that discussed in publications $[4,15]$, where the authors explain that at low load, cerium oxide particles are freely distributed in the fuel, which causes greater accumulation of oxygen around these particles and improves the combustion process. This is especially true for spaces in the combustion chamber with oxygen deficiency. In turn, iron chloride particles, evenly distributed in the fuel injected into the cylinder, go to the vapor fuel zone, where they are the heat generators that initiate the combustion process [30].

In general, the demonstrated variability of the impact of FPC on BSFC with the change in BMEP is consistent with the observations presented in [1,4,22,28,29].

By assessing the emission of exhaust gas components of the tested engine at individual measuring points, the average values presented in Table 7 were obtained.

Table 7. Average emissions of exhaust gas components for various fuels.

\begin{tabular}{ccccc}
\hline & \multicolumn{4}{c}{ Average Emissions, g/kWh } \\
\cline { 2 - 5 } & NO $_{\mathbf{x}}$ & $\mathbf{P M}$ & $\mathbf{C O}$ & THC \\
\hline Pure diesel & 7.32 & 0.18 & 1.29 & 0.89 \\
\hline Diesel with FPC & 7.41 & 0.15 & 1.16 & 0.82 \\
\hline Relative difference, \% & +1.2 & -16.7 & -10.1 & -7.9 \\
\hline
\end{tabular}


The total increase in $\mathrm{NO}_{\mathrm{x}}$ emissions (Table 5) measured during the FPC fuel test can be explained by considering that $\mathrm{NO}_{\mathrm{x}}$ formation in diesel engines occurs due to the reduction of nitrogen as a component of ambient air participating in the fuel combustion process. This reduction is largely dependent on the peak flame temperature, which was higher for the FPC fuel than for the pure fuel; it is the result of a lower water content in the tested fuel and a higher level of distillation at $180{ }^{\circ} \mathrm{C}$, as shown in Table 2.

The reduction in PM emissions is the most noteworthy effect of the use of catalytic additives. The results in Table 5 show that the average PM emission value for the FPC enriched fuel was $16.7 \%$ lower in comparison to pure diesel. This observation is consistent with evidence published in the literature [35-37].

The recorded reduction in CO emissions amounted, on average, to over $10 \%$, and is evidence of a more complete use of oxygen in the combustion process. In turn, the reduction in the average THC emission may be explained by the higher burning rate induced by FPC, which significantly reduced the time for the formation of THC structures.

Obtaining a similar image of emission changes at all measuring points, for the presentation of detailed results, the data for the load characteristic at an engine speed of $2000 \mathrm{rpm}$, which is the speed for the maximum power of the tested engine, were selected; see Figures 4-7.

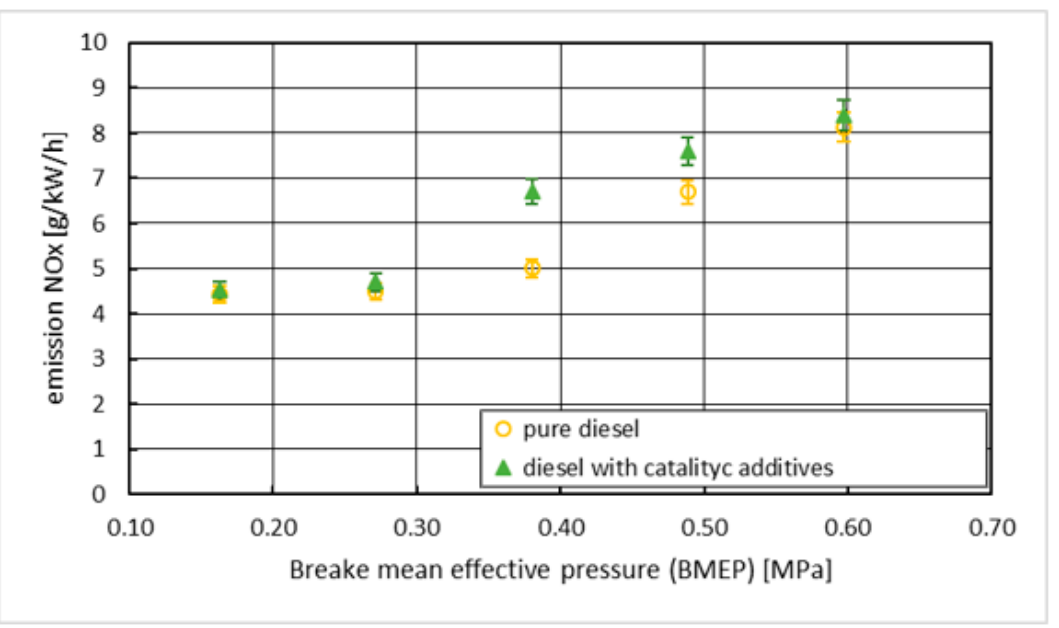

Figure 4. NOx emission vs. brake mean effective pressure at an engine speed of $2000 \mathrm{rpm}$.

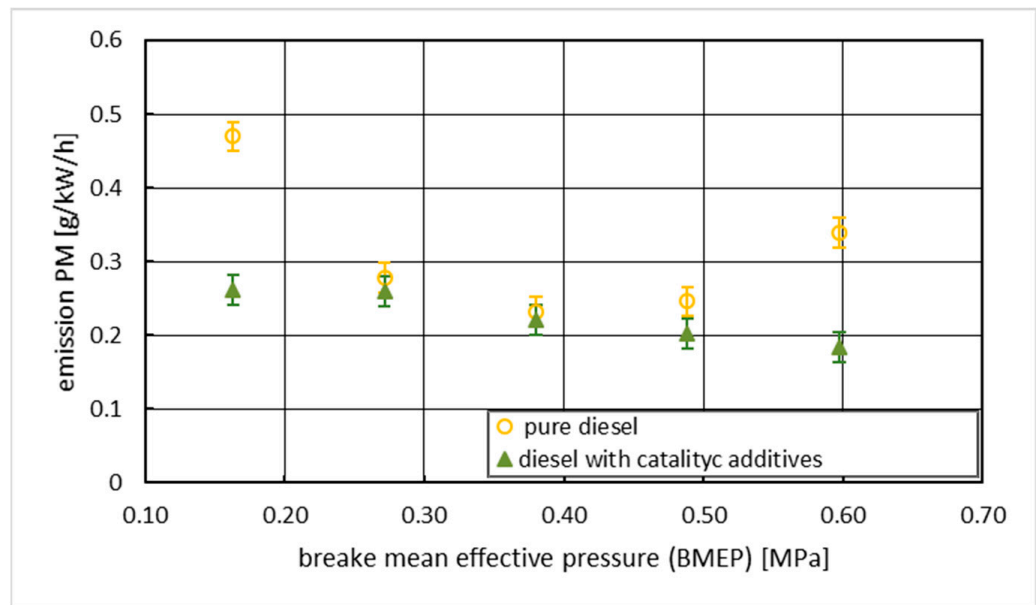

Figure 5. PM emission vs. brake mean effective pressure at an engine speed of $2000 \mathrm{rpm}$. 


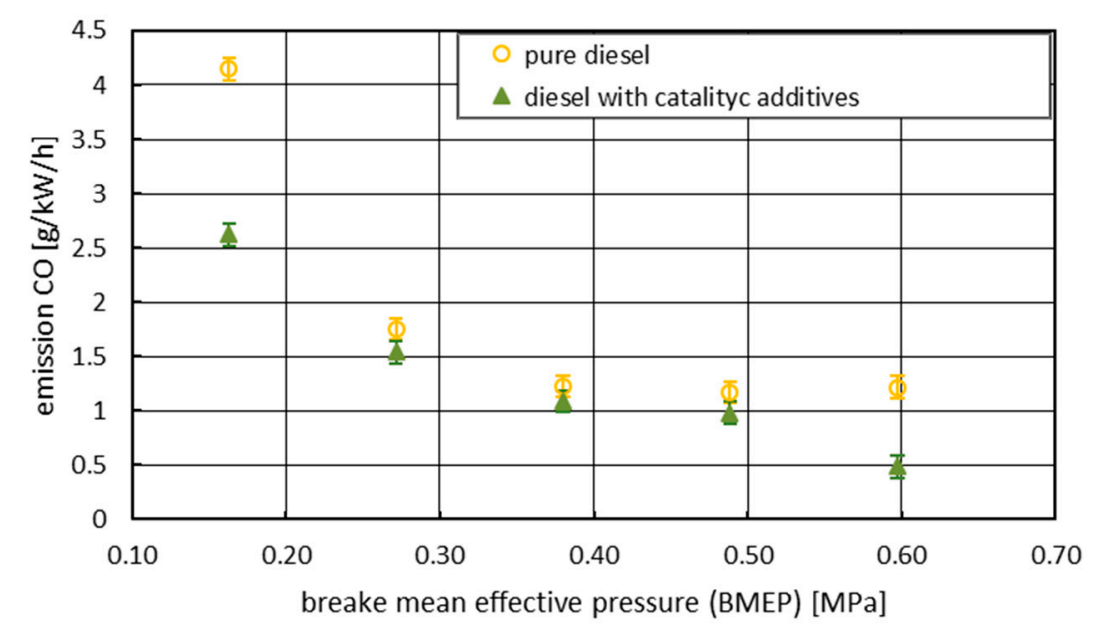

Figure 6. CO emission vs. brake mean effective pressure at an engine speed of $2000 \mathrm{rpm}$.

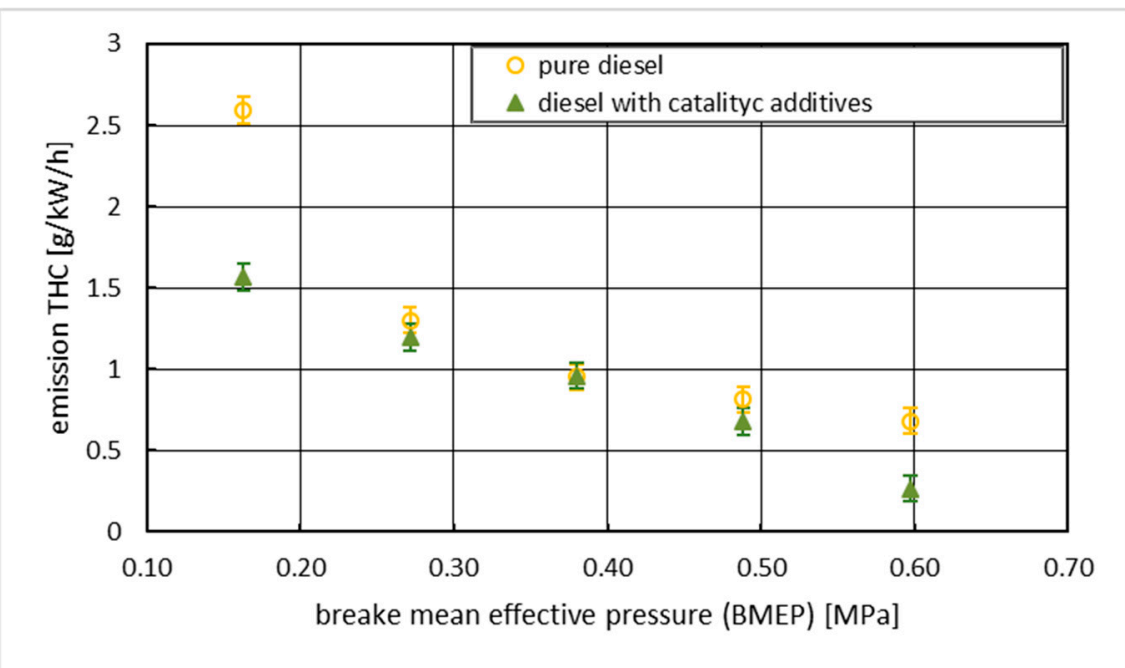

Figure 7. THC emission vs. brake mean effective pressure at an engine speed of $2000 \mathrm{rpm}$.

The nature of changes in $\mathrm{NO}_{x}$ emissions (Figure 4) with changes in engine load is uneven. For average values, i.e., $0.4-0.5 \mathrm{MPa}$, when the highest efficiency occurs in practice, the greatest differentiation of the $\mathrm{NO}_{\mathrm{x}}$ emission values can be observed.

The data in Figure 5 show a strong influence of FPC on PM emissions, especially in low and high load regions. This also resulted in a large difference of mean values (Table 5) compared to a lack of significance in the areas of average BMEP. This observation is consistent with data in the literature, i.e., it has been shown that small quantities of transition metals or metal oxides can drastically increase the oxidation rate of growing soot [35-37].

The greatest differences in the values of $\mathrm{CO}$ emissions among the combustion processes of the tested fuels occurred with the lowest and highest loads (Figure 6). These changes are consistent with the changes for BSFC and PM, and are in contrast to those for $\mathrm{NO}_{\mathrm{x}}$, which is in line with the theory of internal combustion engines. In terms of average loads, there were similar (statistically insignificant) values of carbon monoxides emissions. These results demonstrate greater oxidation of $\mathrm{CO}$ to $\mathrm{CO}_{2}$ in areas with low oxygen excess.

The reduction in average THC emissions (Figure 7) with FPC was $7.9 \%$, but this value varied at different load points, similar to BSFC, PM and CO. The most visible changes 
in THC occurred in the regions of lower thermal efficiency, i.e., especially at low and maximum loads.

\section{Conclusions}

The objective of this research, the results of which are presented herein, was to verify the effects of catalytic additives on combustion engine fuels. Fuel consumption and the emissions of toxic compounds in exhaust gases of a real diesel engine were assessed. The research was carried out as part of a project seeking to adapt the propulsion of inland vehicles to the requirements of the Stage $V$ standard for nonroad engines. Tests were carried out on a brand new Doosan MD196TI diesel engine, and were performed according to the ISO 8178 standard. The tested additive was a commercial fuel performance catalyst (FAMAX) with up to $5 \%$ ferric chloride as the organometallic compound. The proportion of the mixture with the fuel was 1:2000.

As a general conclusion, the benefit of the use of a fuel performance catalyst is supported; this is in line with results obtained by other researchers. In this approach, catalytic fuel additives reduced the average specific fuel consumption by $0.5 \%$. This change is statistically insignificant in view of the measurement error. However, the average emission values decreased, which underlines the ecological importance of the use of the additive. Notably, $16.7 \%$ lower PM average values were recorded for the fuel with the additive compared to pure fuel. For carbon monoxide, the average values also decreased by $10.1 \%$, as did total hydrocarbons (THC) by $7.9 \%$. However, the use of the fuel additive resulted in an increase in nitrogen oxide emissions, the average value of which increased by $1.2 \%$.

In a detailed assessment, it turned out that the changes in the tested parameters varied depending on the engine load, and the trends of these changes were comparable for different rotational speeds across the entire engine operating range. The demonstrated variability of the engine work indices according to load allow the authors to make a scientific conclusion about the relationship between the use of a fuel additive and thermal efficiency, namely: the influence of the fuel catalyst on fuel consumption and exhaust gas emissions decreases with the increase in the thermal efficiency of the engine. The demonstration of this relationship was possible thanks to the adopted research methodology. It was shown that for low load values, the difference in terms of fuel consumption between the use of pure fuel and the fuel with additive was 6\%; for higher loads, it decreased to $3 \%$. It should be pointed out that there was a minimum in terms of this differentiation, which corresponded to the lowest value of fuel consumption; this is consistent with the highest thermal efficiency of the engine. The overall reduction in fuel consumption with the FPC, as well as the load-dependent trends (BMEP) can be explained using data from other publications. The observed phenomenon was similar to that discussed in $[4,15]$, where the authors explained that at low load, cerium oxide particles are freely distributed in the fuel, which causes greater accumulation of oxygen around these particles and improves the combustion process. This is especially true for spaces in the combustion chamber with oxygen deficiencies. In turn, iron chloride particles, evenly distributed in the fuel injected into the cylinder, go to the vapor fuel zone, where they are the heat generators that initiate the combustion process [30]. This method of interpretation was based on detailed tests of exhaust gas emissions, the values of which were lower (except for nitrogen oxides) with the use of catalytic fuel additives.

The authors intend to continue research on fuel additives, especially given the downsizing trend of internal combustion engines and the application of such additives in hybrid vehicles. In line with current research trends in this area, the authors also plan to identify the relationship between the size of catalyst particles and the effects of their use. Therefore, in the near future, the laboratory of the Faculty of Vehicle Engineering at the Wroclaw University of Science and Technology is planning an in-depth analysis of individual fuel components, including catalytic additives, whereby the results published in this work will serve a basis for further research. 
Author Contributions: M.T.-research concept, project supervision, investigation, draft and final version of manuscript; Z.J.S.- - research concept, results consultancy, resources management, support to the final version of manuscript; K.K.--investigation with software support, R.W.-investigation and validation. All authors have read and agreed to the published version of the manuscript.

Funding: This research received no external funding.

Institutional Review Board Statement: Not applicable.

Informed Consent Statement: Not applicable.

Data Availability Statement: The authors declare that they have read the information in section "MDPI Research Data Policies" at https:/ / www.mdpi.com/ethics and fulfill all forms of ethics and good practice in the course of research and publication.

Acknowledgments: This research was supported by using resources GEO-3EM Energy, Ecology, Education co-financed by the European Regional Development Fund. Special thanks to the company Business Consulting AB for providing catalytic additives "ProOne Fuel Maximizer" for research.

Conflicts of Interest: The authors declare no conflict of interest.

\section{References}

1. Zhang, D. Homogeneous combustion catalysts for efficiency improvements and emission reduction in diesel engines. In Proceedings of the 7th Asia-Pacific Conference on Combustion, Taipei, Taiwan, 24-27 May 2009.

2. Popova, O.V.; Bashkatova, S.T.; Vasil'eva, E.N.; Kotin, E.B. Additives for increasing the completeness of combustion of diesel fuels. Chem. Technol. Fuels Oils 1995, 31, 88-94. [CrossRef]

3. Ma, Y.; Zhu, M.; Zhang, D. The effect of a homogeneous combustion catalyst on exhaust emissions from a single cylinder diesel engine. Appl. Energy 2013, 102, 556-562. [CrossRef]

4. Zhu, M.; Ma, Y.; Zhang, D. A theoretical investigation into the effect of a homogeneous catalyst on combustion characteristics of single droplets of diesel and biodiesel. In Proceedings of the Australasian Chemical Engineering Conference, CHEMECA, Wellington, New Zealand, 23-26 September 2012; Volume 11.

5. Zeller, H.W.; Westphal, T.E. Effectiveness of Iron-Based Fuel Additives for Diesel Soot Control; Bureau of Mines: Washington, DC, USA, 1992.

6. Zhu, M.; Ma, Y.; Zhang, D. Effect of a homogeneous combustion catalyst on combustion characteristics and fuel efficiency of biodiesel in a diesel engine. In Proceedings of the International Conference on Applied Energy, Suzhou, China, 5-8 July 2012; pp. 960-967, This is an example of an ordered list.

7. Du, C.J.; Kracklauer, J.; Kittelson, D.B. Influence of an Iron Fuel Additive on Diesel Combustion. SAE Tech. Paper Ser. 1998, 980536. [CrossRef]

8. Bobolev, V.K.; Gen, M.Y.; Mal'tsev, V.M.; Melesov, G.P.; Pokhil, P.F.; Seleznev, V.A.; Stasenko, A.N.; Chuiko, S.V. Mechanism of action of iron catalysts on the combustion of composite systems. Combust. Explos. Shock Waves 1971, 7, 317-324. [CrossRef]

9. Howard, J.B.; Kausch, W.J. Soot control by fuel additive. Prog. Energy Combust. Sci. 1980, 6, 263-276. [CrossRef]

10. Otto, K.; Bartosiewicz, L.; Shelef, M. Effects of calcium, strontium, and barium as catalysts and sulphur scavengers in the steam gasification of coal chars. Fuel 1979, 58, 565-572. [CrossRef]

11. Zhang, Z.; Lu, Y.; Wang, Y.; Yu, X.; Smallbone, A.; Dong, C.; Roskilly, A.P. Comparative study of using multi-wall carbon nanotube and two different sizes of cerium oxide nanopowders as fuel additives under various diesel engine conditions. Fuel 2019, 256, 115904. [CrossRef]

12. Zhang, J.; Nazarenko, Y.; Zhang, L.; Calderon, L.; Lee, K.; Garfunkel, E.; Schwander, S.; Tetley, T.D.; Chung, K.F.; Porter, A.E.; et al. Impacts of a nanosized ceria additive on diesel engine emissions of particulate and gaseous pollutants. Environ. Sci. Technol. 2013, 47, 13077-13085. [CrossRef]

13. Pandey, A.K.; Nandgaonkar, M.; Suresh, S.; Varghese, A. The Effect of Cerium Oxide Nano Particles Fuel Additive on Performance, Combustion, NOx Reduction and Nano Particle Emission of Karanja and Jatropha Biodiesel in a Military 585 kW CIDI Engine. SAE Tech. Paper 2019. [CrossRef]

14. Khalife, E.; Tabatabaei, M.; Najafi, B.; Mirsalim, S.M.; Gharehghani, A.; Mohammadi, P.; Aghbashlo, M.; Ghaffari, A.; Khounani, Z.; Shojaei, T.R.; et al. A novel emulsion fuel containing aqueous nano cerium oxide additive in diesel-biodiesel blends to improve diesel engines performance and reduce exhaust emissions: Part I-Experimental analysis. Fuel 2017, 207, 741-750. [CrossRef]

15. Leach, F.C.P.; Davy, M.; Terry, B. Combustion and emissions from cerium oxide nanoparticle dosed diesel fuel in a high speed diesel research engine under low temperature combustion (LTC) conditions. Fuel 2020, 119636. [CrossRef]

16. Keskin, A.; Guru, M.; Altiparmak, D. Influence of tall oil biodiesel with Mg and Mo based fuel additives on diesel engine performance and emission. Biosour. Technol. 2008, 99, 6434-6438. [CrossRef] [PubMed]

17. Daly, D.T.; McKinnon, D.L.; Martin, J.R.; Pavlich, D.A. A diesel particulate regeneration system using a copper fuel additive. SAE Tech. Paper Ser. 1993, 930131. [CrossRef]

18. Fanick, E.; Valentiine, J. Emissions reduction performance of a bimetallic platinum/cerium fuel borne catalyst with several diesel particulate filters on different sulfur fuels. SAE Tech. Paper Ser. 2001. [CrossRef] 
19. Jelles, S.J.; Makkee, M.; Moulijn, J.A. Ultra low dosage of platinum and cerium fuel additives in diesel particulate control. Top. Catal. 2001, 16-17, 269-273. [CrossRef]

20. Kelso, D.T.; Epperly, W.; Hart, M. Effects of platinum fuel additive on diesel emissions and efficiency. SAE Tech. Paper Ser. 1990, 901492. [CrossRef]

21. Krutzsch, B.; Wenninger, G. Effect of sodium- and lithium-based fuel additives on the regeneration efficiency of diesel particulate filters. SAE Tech. Paper Ser. 1992, 922188. [CrossRef]

22. Zhu, M.; Ma, Y.; Zhang, D. An experimental study of the effect of a homogeneous combustion catalyst on fuel consumption and smoke emission in a diesel engine. Energy 2011, 36, 6004-6009. [CrossRef]

23. Cho, S.-H.; Yoo, J.-I.; Turley, A.T.; Miller, C.A.; Linak, W.P.; Wendt, J.O.; Huggins, F.E.; Gilmour, M.I. Relationships between composition and pulmonary toxicity of prototype particles from coal combustion and pyrolysis. Proc. Combust. Inst. 2009, 32, 2717-2725. [CrossRef]

24. Fairbairn, E.A.; Keller, A.A.; Madler, L. Metal oxide nanomaterials in seawater: Linking physicochemical characteristics with biological response in sea urchin development. J. Hazard. Mater. 2011, 192, 1565-1571. [CrossRef]

25. Falugi, C.; Aluigi, M.G.; Chiantore, M.C. Toxicity of metal oxide nanoparticles in immune cells of the sea urchin. Mar. Environ. Res. 2012, 76, 114-121. [CrossRef] [PubMed]

26. Ma, Y.; Zhu, M.; Zhang, Z.; Zhang, D. Effect of a Homogeneous Combustion Catalyst on the Nanostructure and Oxidative Properties of Soot from Biodiesel Combustion in a Compression Ignition Engine; Corpus ID: 56163840; Elsevier BV: Amsterdam, The Netherlands, 2015; Volume 35, pp. 1947-1954.

27. Platt, R.A. Reduction in Greenhouse Gas Emissions by Application of a Combustion Catalyst; Fuel Technology Pty Ltd.: Kewdale, Western Australia, 1999.

28. Zhang, D.; Ma, Y.; Zhu, M. Nanostructure and oxidative properties of soot from a compression ignition engine: The effect of a homogeneous combustion catalyst. Proc. Combust. Inst. 2013, 34, 1869-1876. [CrossRef]

29. Zhu, M.; Ma, Y.; Zhang, D. Effect of a homogeneous combustion catalyst on the combustion characteristics and fuel efficiency in a diesel engine. Appl. Energy 2012, 91, 166-172. [CrossRef]

30. Zhang, D.; Zhu, M.; Ma, Y.; Millin, N. Homogeneous Combustion Catalysts for Efficiency Improvements and Emission Reduction in Diesel Engines; Handbook of Clean Energy Systems by John Wiley \& Sons, Ltd.: Hoboken, NJ, USA, 2015. [CrossRef]

31. Staude, S.; Hecht, C.; Wlokas, I.; Schulz, C.; Atakan, B. Experimental and numerical investigation of FeCO $\mathrm{O}_{5}$ to a laminar premixed hydrogen flame. Z. Phys. Chem. 2009, 223, 639-649. [CrossRef]

32. Linteris, G.T.; Babushok, V.I. Promotion or inhibition of hydrogen-air ignition by iron containing compounds. Proc. Combust. Inst. 2009, 32, 2535-2542. [CrossRef]

33. Li, S.; Wei, X.L. Promotion of CO oxidization and inhibition of NO formation by gaseous iron species during hightemperature off-gas combustion. Energy Fuels 2011, 25, 967-974. [CrossRef]

34. Park, K.; Bae, G.T.; Shin, K.S. The addition effect of $\mathrm{FeCO}_{5}$ on methane ignition. Bull. Korean Chem. Soc. 2002, 23, 175-176.

35. Stratakis, G.A.; Stamatelos, A.M. Thermogravimetric analysis of soot emitted by a modern diesel engine run on catalystdoped fuel. Combust. Flame 2003, 132, 157-169. [CrossRef]

36. Kim, S.H.; Fletcher, R.A.; Zachariah, M.R. Understanding the difference in oxidative properties between flame and diesel soot nanoparticles: The role of metals. Environ. Sci. Technol. 2005, 39, 4021-4026. [CrossRef]

37. Song, J.H.; Wang, J.G.; Boehman, A.L. The role of fuelborne catalyst in diesel particulate oxidation behavior. Combust. Flame 2006, 146, 73-84. [CrossRef]

38. Heidari-Maleni, A.; Gundoshmian, T.M.; Jahanbakhshi, A.; Ghobadian, B. Performance improvement and exhaust emissions reduction in diesel engine through the use of graphene quantum dot (GQD) nanoparticles and ethanol-biodiesel blends. Fuel 2020, 267, 117116. [CrossRef]

39. ProOne Fuel Maximizer-Safety Data Sheet. Available online: www.pro-one.us (accessed on 25 March 2015).

40. Kim, H.J.; Lee, S.H.; Kwon, S.I.; Park, S.; Lee, J.; Keel, J.H.; Lee, J.T.; Park, S. Investigation of the Emission Characteristics of Light-Duty Diesel Vehicles in Korea Based on EURO-VI Standards According to Type of After-Treatment System. Energies 2020, 13, 4936. [CrossRef]

41. Azad, A.K.; Rasul, M.G.; Sharma, S.C.; Khan, M.M.K. The Lubricity of Ternary Fuel Mixture Blends as a Way to Assess Diesel Engine Durability. Energies 2018, 11, 33. [CrossRef]

42. Doosan, Daewoo-Marine Diesel Engine. Available online: http:/ /iv.doosaninfracore.com (accessed on 5 July 2018). 